\title{
Os Belfort Mattos e os Arquivos Brasileiros de Oftalmologia
}

\author{
Harley E. A. Bicas
}

Junho de 1938. Um tempo em que se viajava por trens e balões dirigíveis (o maior deles, o Graf Zeppelin II sequer havia sido inaugurado) e ainda não se construíra o helicóptero, televisores, nem nosso primeiro carro nacional; a Segunda Guerra Mundial não começara, o Brasil com cerca de 40 milhões de habitantes vivia sob o regime de "Estado Novo" no governo de Getúlio Vargas e interventores estaduais, enquanto a cidade de São Paulo não chegava a um décimo de sua população atual. Não existiam Brasília, Pelé, os Estádios do Pacaembu e do Maracanã, nem Roberto Carlos, Caetano ou Chico; ainda se usava a mesma moeda da época do descobrimento: com um tostão (100 réis) comprava-se um sorvete. Mas a penicilina não era fabricada e nem se conhecia o fator Rh. Então Waldemar Rangel Belfort Mattos, nos seus 41 anos, fundava os Arquivos Brasileiros de Oftalmologia.

Passou a guerra, veio a "fria" e se acabou. A U.R.S.S. virou potência mundial, mas também se despedaçou. Por aqui, tivemos de quase tudo, pelo menos um pouco. E enquanto isso, os Arquivos Brasileiros de Oftalmologia se consolidavam e fortaleciam, sempre sob a responsabilidade e patrocínio dos Belfort Mattos. A Waldemar, falecido nos últimos dias de 1956, sucedia-lhe Rubens, o pai, que já em 1950 aparece como Secretário. Os Arquivos, ainda embora sustentados pela família, desde havia muito transcendiam de sua esfera, passando a ser um patrimônio da Oftalmologia brasileira. E o que então já era fato, vira direito em 1977, quando o Conselho Brasileiro de Oftalmologia os incorpora como seu "órgão oficial" (a partir do $\mathrm{n}^{\circ} 4$ do volume 40). Rubens, Júnior, desde sua formatura comprometido com as tarefas exigidas para manter a periodicidade e qualidade das publicações passa, em 1979, a dividir com Rubens, pai, a incumbência de dirigir o projeto, incorporando-se, oficialmente, à sua administração. Assim foi. E prosseguindo sob a orientação do "terceiro" Belfort Mattos, todavia mais se aprimorava essa nossa revista: novo formato (1990), expansão editorial, publicação eletrônica, uma das primeiras do Brasil. Um dos grandes orgulhos é a sua continuida- de, com edições ininterruptas desde a fundação, o que não é fácil para um periódico científico. Nesse tempo, muitos já surgiram e desapareceram.

Chega um momento em que Rubens, Júnior, assumindo novas e enormes responsabilidades (a Presidência do Congresso Internacional de Oftalmologia em 2006; a do Brasileiro de 2001, a da Associação Pan-Americana de Oftalmologia, de 2001 a 2003), além das que já mantinha em sua casa, na UNIFESP, julga oportuna e conveniente sua substituição na coordenação do Conselho Editorial dos A.B.O. e na administração das publicações. Realiza um seu antigo desejo de ver os A.B.O. definitivamente transferidos ao C.B.O. Deixa a casa arrumada e funcionando, com estrutura e regularidade; de tal sorte que parece até fácil substituí-lo agora e dar seqüência e regularidade a essa obra gigantesca. Dele e de sua família.

Ao contrário, é muito difícil. Tentaremos, no entanto. Mas é um novo passo, quando os Belfort Mattos, representados pelo Rubens, Júnior, serena e corajosamente confiam, definitivamente, os A.B.O. ao C.B.O. Há que se lhes agradecer, muito e sempre, os enormes esforços despendidos, os gastos, os sacrifícios de toda ordem e, possivelmente, até de amizades, para que a grandeza da empreitada não fosse maculada. Há que se render homenagens ao neto, reverenciando a memória do pai e do avô. E um pouco dessa gratidão da Oftalmologia brasileira fica oficialmente representada pela carta de intenções com que se formaliza e celebra essa nova fase, quando uma família (Belfort Mattos) dá a outra (a Oftalmologia brasileira), sua filha em casamento: preservando a dignidade de independência dessa "jovenzinha" (62 anos são poucos para uma Revista), garantindo-lhe que jamais ela possa ficar subordinada a ambições políticas e assegurando-lhe que sempre prevaleçam os ideais que até agora a sustentaram: os do valor da ciência, os da virtude da ética, os do bom e equilibrado crescimento da Oftalmologia brasileira.

Aos Belfort Mattos, por tudo que nos legaram, nosso muitíssimo obrigado.

\section{Novidades na Internet!:!}

Agora no site CBO você tem disponível todas as informações na íntegra dos

Arquivos Brasileiros de Oftalmologia

http://w w w.cho.com.br/abo 